\title{
Influence of culture conditions and preconditioning on survival of Lactobacillus delbrueckii subspecies bulgaricus ND02 during lyophilization
}

\author{
Yuyu Shao, Shuran Gao, Huiling Guo, and Heping Zhang ${ }^{1}$ \\ Key Laboratory of Dairy Biotechnology and Engineering, Ministry of Education, Inner Mongolia Agricultural University, Huhhot, \\ Inner Mongolia 010018, P. R. China
}

\begin{abstract}
The cryotolerance of Lactobacillus delbrueckii ssp. bulgaricus is weak during vacuum freeze-drying. Many factors affect cryoresistance of these bacteria, such as cryoprotectant composition, the lyophilization technology used, and the intrinsic characteristics of the bacteria. In this research, we explored the fermentation technology and other preconditioning treatments of cells in improving the cryoresistance of Lactobacillus delbrueckii ssp. bulgaricus strains during lyophilization. The addition of yeast extract in the propagation medium exerted a negative effect on the cryotolerance of these bacteria and decreased survival during lyophilization. The count of the freeze-dried cells from medium containing a high level $(4 \%)$ of yeast extract was only $4.1 \times 10^{9} \mathrm{cfu} / \mathrm{g}$, indicating a death rate as high as $88 \%$, compared with the culture medium without yeast extract, with a lower death rate of $44.7 \%$. When Lactobacillus delbrueckii ssp. bulgaricus ND02 was propagated in yeast extract-free de Man, Rogosa, and Sharpe broth at a set $\mathrm{pH}$ value of 5.1, the cells showed unexpectedly higher survival after freeze-drying. Viable counts of the lyophilized cell of strain ND02 cultivated at $\mathrm{pH} 5.1$ could reach $1.05 \times$ $10^{11} \mathrm{cfu} / \mathrm{g}$ and survival of the freeze-drying process was $68.3 \%$, whereas at $\mathrm{pH} 5.7$, survival was only $51.2 \%$. We also examined the effects of pretreatment of cells on survival of the bacteria after vacuum freeze-drying. By analyzing the effect of pretreatment conditions on the expression of cold- and heat-shock genes, we established 2 pretreatments that improved survival of cells after lyophilization. Optimal fermentation conditions and pretreatment of the cell-cryoprotectant mixture at $10^{\circ} \mathrm{C}$ for $2 \mathrm{~h}$ or $37^{\circ} \mathrm{C}$ for 30 min improved the cryoresistance of 4 strains of Lactobacillus delbrueckii ssp. bulgaricus to varying degrees. Cells of IMAU20269 and IMAU20291 that were pretreated showed enhanced survival of 16.06 and $16.82 \%$, respectively, after lyophilization. Expres-
\end{abstract}

Received September 28, 2013.

Accepted November 8, 2013.

${ }^{1}$ Corresponding author: hepingdd@vip.sina.com sion of cold- and heat-shock genes for pretreated strains ND02, IMAU80423, IMAU20269, and IMAU20291 was analyzed by using quantitative PCR. From the expression of 2 cold shock-induced genes ( $\operatorname{spp} \mathrm{A}$ and $c s p \mathrm{~B})$ and 6 heat shock-induced genes (groES, hsp, hsp20, hsp40, hsp60, and hsp70), strain ND02 showed a higher relative quantity of gene expression and displayed superior resistance to cold-induced stress during the freezedrying process.

Key words: Lactobacillus delbrueckii ssp. bulgaricus ND02, cryoresistance, cryotolerance

\section{INTRODUCTION}

Lactobacillus delbrueckii ssp. bulgaricus (hereafter referred to as Lactobacillus bulgaricus) is one of the most important bacteria in dairy fermentations. It is used as a component starter in the production of yogurt and Italian and Swiss variety cheeses. Yogurt is gaining popularity in China, and the demand for yogurt will continue to grow rapidly. More starter culture strains are needed in dairy industry for the manufacture of yogurt. Lyophilized starter cultures have several advantages over frozen cultures, such as economy in storage space, convenience in shipping, and lower energy cost for storage either at normal refrigeration temperatures or at ambient temperatures. In our laboratory, we are engaged in developing suitable technology for growing and preserving selected strains of lactic acid bacteria isolated from indigenous fermented dairy products for use in yogurt production. In industrial production of yogurt starters, $L b$. bulgaricus strains are subjected to cold shock by preservative techniques such as frozen storage and vacuum freeze-drying. These techniques influence the quality and functionality of starter cultures and the fermented products made using them. Losses in viability and functionality have to be minimized to ensure efficient and successful manufacture of yogurt.

The survival and low temperature stability of starters obtained by vacuum freeze-drying are governed by several factors. They include the strain characteristic; fermentation conditions such as the composition of 
the culture medium, temperature, and $\mathrm{pH}$ control; and the neutralizer used. Other factors also affect the cryotolerance and cryoresistance of the bacteria. Streit et al. (2010) investigated the steps affecting the cryotolerance of $L b$. bulgaricus CFL1. They found that the speed and duration of centrifugation affected the cryotolerance of the cell concentrate and that optimal conditions during centrifugation improved the cryostability of the cells. Other studies found that harvesting conditions, the acidity of the fermentation, postharvest handling of the concentrate such the rate of cooling, and washing of cell concentrate with different reagents all affected the cryostability of cultures (Fonseca et al., 2001; Saarela et al., 2005; Wang et al., 2005b; Streit et al., 2007). Additionally, the technology of lyophilization is also critical in ensuring cryostability, because vacuum freeze-drying is a complicated process. It is not just freezing the material being dried and carrying out sublimation under vacuum. The temperature of the frozen material should be increased carefully through a gradient over time, such that the eutectic barrier of the frozen substrate is not breached. The aim is to obtain a highly efficient sublimation aided by vacuum to obtain maximum cell survival. In regard to survival to freezing, Bâati et al. (2000) found that a gradual step-wise decrease in temperature through a range of $37^{\circ} \mathrm{C}, 20^{\circ} \mathrm{C}$, $-4^{\circ} \mathrm{C},-20^{\circ} \mathrm{C}$, and $-80^{\circ} \mathrm{C}$ yielded greater survival of a strain of Lactobacillus acidophilus compared with direct one-step freezing at $-80^{\circ} \mathrm{C}$. Recent work has revealed that the cooling-thawing rate and preconditioning of the cells, which affect cryostress, could be optimized through an analysis of cold- and heat-shock proteins and expression of related genes. Several studies have investigated the cold- and heat-shock response and adaptation in Escherichia coli and Bacillus subtilis (Hecker and Völker, 1990; Jones et al., 1992; Willimsky et al., 1992; Bukau, 1993; Storz and Hengge-Aronis, 2000), but not much is known about such responses in $L b$. bulgaricus. The family of cold-shock protein (csp) genes, designated $c s p \mathrm{~A}, c s p \mathrm{~B}, c s p \mathrm{C}, c s p \mathrm{D}$, and $c s p \mathrm{E}$, that encode very similar cold-shock proteins has been described in the lactic acid bacterium Lactococcus lactis MG1363 (Wouters et al., 1998). Komatsu et al. (1990) demonstrated that the enhanced induction of such genes and gene products improved the cryoresistance of bacteria. Hence, a better understanding of the responses and allied mechanisms in Lb. bulgaricus strains might contribute to greater cryostability of these industrially important bacteria during freezing and subsequent lyophilization. Analysis of different pretreatments of $L b$. bulgaricus and the expression of cold- and heat-shock genes and gene products could provide a means to develop efficient cryostability of these bacteria.
In this study, we examined the effects of several factors on the cryostability of $L b$. bulgaricus strains; namely, the nutrient composition of the propagation medium, the $\mathrm{pH}$ set point during propagation in a fermentor, and preconditioning of the cell crop at different time-temperature treatments and resultant induction and expression of $c s p$ and heat-shock protein (hsp) genes and gene products. Based on the results, we propose a set of optimized and reliable protocols for freezing, frozen storage, and lyophilization of $L b$. bulgaricus. These protocols could be adapted to preserve other cryosensitive bacteria. The observations made in this study could be extended to developing procedures for successful industrial production of starter cultures for dairy and food industries.

\section{MATERIALS AND METHODS}

\section{Bacterial Strains, Culture Media, and Growth Conditions}

Lactobacillus bulgaricus strains ND02, IMAU80423, IMAU20269, and IMAU20291 used in this study were isolated from traditional naturally fermented milks made by Chinese minority groups living in different geographical areas in China. These strains were obtained from the culture collection at the Key Laboratory of Dairy Biotechnology and Engineering, Ministry of Education, Inner Mongolia Agricultural University, China. Previous study in our laboratory has shown that strains ND02 and IMAU80423 have relatively higher cryostability during freeze-drying compared with strains IMAU20269 and IMAU20291 (Bao, 2012).

Strain ND02 was of special interest to us. This strain was isolated from naturally fermented yak milk in Qinghai province and was the predominant strain in the sample (Sun et al., 2010). Yogurt made with this strain was judged to be of excellent quality, displaying moderate acidity, high viscosity, and good water-holding capacity. Additionally, the whole-genome sequencing of this strain was completed in 2011. It had been adapted for industrial production for use as yogurt starter by the largest dairy group in China, the Inner Mongolia Yili Industrial Group (Sun et al., 2011a).

\section{Routine Propagation of Strains}

Lactobacillus bulgaricus strains were activated by growing in sterilized $10 \%$ (wt/vol) skim milk $\left(121^{\circ} \mathrm{C}\right.$ for $7 \mathrm{~min}$ ). The activated cultures were propagated in de Man, Rogosa, and Sharpe (MRS) broth (sterilized at $121^{\circ} \mathrm{C}$ for $15 \mathrm{~min}$ ) using a 1 to $2 \%$ inoculum and incubation at $37^{\circ} \mathrm{C}$ for $12 \mathrm{~h}$. 


\section{Influence of Yeast Extract in MRS Broth Used to Grow Strain ND02 in the Fermentor}

To study the effect of different concentrations of yeast extract in MRS broth on cryostability, Lb. bulgaricus ND02 was grown in MRS broths containing 0, 2 , or $4 \%$ yeast extract. Sterile MRS broths containing variable levels of yeast extract were pumped into three 5-L fermentors (Eastbio, GUJS-5, Zhenjiang East Biotech Equipment and Technology Co. Ltd., Zhenjiang, China) installed in parallel. The initial $\mathrm{pH}$ was adjusted to $6.5, \mathrm{pH}$ during fermentation was set at 5.7 , and the fermentation temperature was controlled at $37^{\circ} \mathrm{C}$. The fermentation parameters were electronically controlled and recorded in a computer attached to the fermentors. At the end of fermentation (determined by the cessation of neutralizer-25\% ammonia water addition), samples were removed from individual fermentors to determine cell morphology using a photon microscope (DM4000B, Leica, Wetzlar, Germany). The remaining broths were individually harvested by centrifugation $(5,116 \times g$ for 10 min at $4^{\circ} \mathrm{C}$ ). The sedimented cells were washed twice using buffer solution $\left(0.8 \% \mathrm{NaCl}, 0.02 \% \mathrm{KH}_{2} \mathrm{PO}_{4}\right.$, and $0.115 \% \mathrm{Na}_{2} \mathrm{PO}_{4}$, wt/vol). The washed cells were mixed with a cryoprotective agent consisting of $10 \%$ skim milk fortified with $1 \%$ sodium glutamate in the ratio of 1:6. Cell counts of the cell-cryoprotective mixture were determined by plate count method. The mixtures were then frozen at $-40^{\circ} \mathrm{C}$ and held for $2.5 \mathrm{~h}$ before freezedrying. Bacterial counts on dried powders were made by plate counts (viable count; VC) and the survival of cells from the individual fermentations was calculated according to the following formula:

Survival $(\%)=$

$\mathrm{VC}$ of lyophilized powder $\times \mathrm{Wt}$ of lyophilized powder

$\mathrm{VC}$ of cell protectant $\times \mathrm{Wt}$ of of cell protectant

\section{Relationship Between $\mathrm{pH}$ and Cryotolerance of Lyophilized Lb. bulgaricus ND02}

Lactobacillus bulgaricus ND02 was activated as described earlier, and $2 \%$ of the activated culture was inoculated into sterile MRS broth and incubated at $37^{\circ} \mathrm{C}$ for $12 \mathrm{~h}$. The fermentors (5-L capacity) installed in parallel, were designated as F1 and F2 and were filled with yeast extract-free MRS broth (3 L each). Each of the fermentors was inoculated with $30 \mathrm{~mL}$ of aforementioned MRS broth culture. The initial $\mathrm{pH}$ of both fermentors was adjusted to 6.5 . The $\mathrm{pH}$ for $\mathrm{F} 1$ was set at 5.7 and for F2 at 5.1. The fermentation temperature was set at $37^{\circ} \mathrm{C}$. The fermentation parameters were continuously monitored and recorded by the computer connected to the fermentors. The end of fermentation was determined as described in the previous section. At the end of fermentation, samples from F1 and F2 were taken to examine the morphology of the cells under light microscope. The image of the bacteria was captured by software LAS V3.7 (Leica Microsystems Ltd., Heerbrugg, Switzerland) and the measurement of length of the cells was carried out using Leica QWin V3. The postfermentation operations (harvesting cells, washing cells, addition of cryoprotectants, sampling for plate counts, freezing, and lyophilization) were carried out as outlined in the previous section. The percentage survival of cells after freeze-drying was calculated using the same formula described in the previous section.

\section{Assaying the Functionality of the Lyophilized Powders}

To determine the functionality of the freeze-dried powders, acid-producing activity of the dried cultures in milk at standard conditions was measured. The powders were reconstituted in $0.8 \%$ (wt/vol) $\mathrm{NaCl}$ so that $1.0 \times 10^{7} \mathrm{cfu} / \mathrm{mL}$ could be added to sterile $10 \%$ skim milk. After incubating the inoculated milks at $42^{\circ} \mathrm{C}$ for 4 and $6 \mathrm{~h}$, the $\mathrm{pH}$ and titratable acidity of the milks were recorded (Zhang and Zhang, 2007).

\section{Cold- and Heat-Shock Pretreatment}

Lactobacillus bulgaricus strains ND02, IMAU80423, IMAU20269, and IMAU20291 were activated as described earlier and grown in MRS broth until the cells reached the exponential growth phase. The cells were then harvested by centrifugation $\left(6,000 \times g\right.$ at $4^{\circ} \mathrm{C}$ for $10 \mathrm{~min}$ ). Harvested cells were washed thrice in buffer solution mentioned above. One-gram portions of the washed cells from each of the 4 strains were transferred into separate Eppendorf tubes in triplicate. The cellloaded Eppendorf tubes were incubated at 4, 7, and $10^{\circ} \mathrm{C}$ for $2 \mathrm{~h}$. After incubation, the samples were tested using real-time quantitative PCR (qPCR) for the determination of cold-shock induction of the $\operatorname{csp} \mathrm{A}$ and $c s p$ B genes. The experiment was repeated twice.

To determine the heat-shock responses, $1.0 \mathrm{~g}$ of cells prepared as described earlier were transferred in triplicate into Eppendorf tubes and incubated for $30 \mathrm{~min}$ at 30,37 , and $45^{\circ} \mathrm{C}$. The gene expression of groES, hsp, $h s p 20, h s p 40, h s p 60$, and $h s p 70$ was evaluated by qPCR.

\section{RNA Extraction and cDNA Synthesis}

Total cellular RNA was extracted from cells treated at different conditions using RNAiso Plus (TaKaRa, Dalian, China) according to the manufacturer's instructions. Genomic DNA elimination was performed 
Table 1. Primer information for cold- and heat-induced genes evaluated in the study

\begin{tabular}{|c|c|c|c|c|}
\hline Primer $^{1}$ & Primer sequence $\left(5^{\prime} \rightarrow 3^{\prime}\right)$ & $\operatorname{Tm}^{2}\left({ }^{\circ} \mathrm{C}\right)$ & Length (bp) & Gene function \\
\hline $\operatorname{csp} \mathrm{A}-\mathrm{F}$ & GCTTTGGGTTTATCAC & 41.0 & 16 & Cold-induced genes \\
\hline $\operatorname{csp} \mathrm{A}-\mathrm{R}$ & ATTAGTCGCTTGAGGT & 42.8 & 16 & \\
\hline $\operatorname{csp} \mathrm{B}-\mathrm{F}$ & GCGAACCGGACTTGTA & 47.8 & 16 & \\
\hline $\operatorname{csp} \mathrm{B}-\mathrm{R}$ & AGCCCTCCTCCTTGAT & 46.8 & 16 & \\
\hline groES-F & AACTTCATCGCCCTCT & 45.7 & 16 & Heat-induced genes \\
\hline groES-R & CAAACTGTTGGTGGTAT & 43.0 & 17 & \\
\hline$h s p-\mathrm{F}$ & TATCCCGCCTGGTCAA & 47.9 & 16 & \\
\hline$h s p-\mathrm{R}$ & TACATCGCCGACAACC & 47.9 & 16 & \\
\hline$h s p 20-\mathrm{F}$ & TTGGCGCTAATGCCTTTC & 50.4 & 18 & \\
\hline hsp $20-\mathrm{R}$ & GATCACATGGGCGACTGG & 52.2 & 18 & \\
\hline hsp40-F & GGAATCACGACCTCAACCG & 52.6 & 19 & \\
\hline hsp 40-R & AGACCCAGAAGCAGACCCT & 53.8 & 19 & \\
\hline hsp60-F & AGCGATGATTAGGAGTGAGC & 51.4 & 20 & \\
\hline$h s p 60-\mathrm{R}$ & TCGGCAAGGACGGTGTTA & 52.8 & 18 & \\
\hline$h s p 70-\mathrm{F}$ & GATGAAGACGACGAAACTG & 48.4 & 19 & \\
\hline hsp70-R & GGAGATGAAAGGAAGGGAG & 48.4 & 19 & \\
\hline gyrB-F & TGCCAGCCAGATTCAA & 46.8 & 16 & Reference gene \\
\hline gyr B-R & ATGGTCCCGTGTTCAGT & 49.3 & 17 & \\
\hline
\end{tabular}

in a $10-\mu \mathrm{L}$ DNA elimination reaction solution containing $2 \mu \mathrm{L}$ of $5 \times \mathrm{gDNA}$ Eraser Buffer (TaKaRa), $1 \mu \mathrm{L}$ of gDNA Eraser (TaKaRa), $1 \mu \mathrm{L}$ of total RNA (500 ng of total RNA), and $6 \mu \mathrm{L}$ of RNase-free distilled $\mathrm{H}_{2} \mathrm{O}$. The DNA present in the total RNA was eliminated by heating the DNA elimination reaction solution at $42^{\circ} \mathrm{C}$ for 2 min. The purified RNA from each sample was reverse-transcribed with PrimeScript RT reagent kit with gDNA Eraser (TaKaRa) according to the manufacturer's instructions. Reverse transcriptions were performed in a $20-\mu \mathrm{L}$ reverse transcription mixture containing $10 \mu \mathrm{L}$ of total RNA $(1 \mu \mathrm{g}$ of total RNA, DNase-treated), $4 \mu \mathrm{L}$ of $5 \times$ PrimeScript Buffer 2 (TaKaRa), $1 \mu \mathrm{L}$ of PrimeScript RT Enzyme Mix I (TaKaRa), $1 \mu \mathrm{L}$ of RTPrimer Mix, and $4 \mu \mathrm{L}$ of RNasefree distilled $\mathrm{H}_{2} \mathrm{O}$. Reverse transcription reaction conditions were $37^{\circ} \mathrm{C}$ for $15 \mathrm{~min}$ followed by $85^{\circ} \mathrm{C}$ for $5 \mathrm{~s}$. The total RNA and cDNA concentrations were quantified by measuring the optical density at $260 \mathrm{~nm}\left(\mathrm{OD}_{260}\right)$ and $280 \mathrm{~nm}\left(\mathrm{OD}_{280}\right)$, respectively, using a NanoDrop ND-1000 spectrophotometer (NanoDrop Technologies, Wilmington, DE).

\section{Quantitative PCR}

The primer pairs for the $\mathrm{qPCR}$ were designed based on the whole genome of $L b$. bulgaricus ND02 using the Primer Premier 5.0 software (Premier Biosoft International, Palo Alto, CA; Table 1). Primers were synthesized by Sangni Biosciences Corporation (Shanghai, China).

All qPCR assays were carried out in a 48-well plate using StepOnePlus Real-Time PCR System (Applied
Biosystems, Carlsbad, CA) in accordance with the manufacturer's instructions. The qPCR reactions were carried out using SYBR Premix Ex Taq II (TaKaRa) and samples were tested in triplicate. The reactions were done in a $20-\mu \mathrm{L}$ volume containing $10 \mu \mathrm{L}$ of $2 \times$ SYBR Premix Ex Taq, $0.8 \mu \mathrm{L}$ of forward primer $(10 \mu M), 0.8$ $\mu \mathrm{L}$ of reverse primer $(10 \mu M), 0.4 \mu \mathrm{L}$ of $50 \times \mathrm{ROX}$ Reference Dye II, $2 \mu \mathrm{L}$ of $\mathrm{cDNA}$, and $6 \mu \mathrm{L}$ of distilled $\mathrm{H}_{2} \mathrm{O}$. The cDNA concentrations were adjusted to approximately $100 \mathrm{ng} / \mu \mathrm{L}$ by adding distilled $\mathrm{H}_{2} \mathrm{O}$. Sterile ultrapure water was substituted for DNA in the negative control for detecting possible contamination. Relative normalized fluorescence change $(\Delta R n)$ was plotted against time (PCR cycle number) to facilitate real-time assessment of each PCR. For each sample, the amount of cold-shock induced genes $c s p \mathrm{~A}$ and $c s p \mathrm{~B}$ mRNA was quantified by real-time qPCR. The calculated cycle threshold $(\mathrm{Ct})$ provides an arbitrary cut-off point at which a $\mathrm{Ct}$ value is assigned for the individual samples.

\section{Statistical Analyses}

Statistical analysis for the mean relative expression levels for the genes related to cold- and heat-shock genes was conducted using the StepOne software v2.2 (Applied Biosystems). Statistical analysis of the routine data was performed using Data Processing System (DPS) 6.55 (Zhejiang University and Hangzhou Rui Feng Information Technology Co. Ltd., Hangzhou, China). Figures presented in this paper were plotted using software GraphPad Prism 5.01 (GraphPad Inc., San Diego, CA). All results are expressed as means \pm standard deviation (SD). 
Table 2. Results of fermentations with $\mathrm{pH}$ controlled at 5.1 and 5.7

\begin{tabular}{llc}
\hline Item & $\mathrm{pH} 5.1$ & $\mathrm{pH} 5.7$ \\
\hline Viable count of the fermented broth (cfu/mL) & $4.3 \times 10^{9}$ & $8.9 \times 10^{9}$ \\
Viable count of the lyophilized powder (cfu/g) & $1.05 \times 10^{11}$ & $6.2 \times 10^{10}$ \\
Survival of the freeze-drying process (\%) & 68.3 & 51.2 \\
Consumption of neutralizer (mL) & 80 & 110 \\
Fermentation time (h) & 11.5 & 7 \\
\hline
\end{tabular}

\section{RESULTS AND DISCUSSION}

\section{Influence of Yeast Extract on Survival of Cells During Vacuum Freeze-Drying}

In this study, the higher level of yeast extract $(4 \%)$ yielded a high viable count in the fermented broth $(1.15$ $\times 10^{10} \mathrm{cfu} / \mathrm{mL}$ ) and a short fermentation time $(6 \mathrm{~h})$ for Lactobacillus bulgaricus ND02. However, the count of freeze-dried cells from medium containing a high level of yeast extract was only $4.1 \times 10^{9} \mathrm{cfu} / \mathrm{g}$, indicating a death rate as high as $88 \%$. In contrast, the culture medium without yeast extract yielded better survivability to freeze-drying. In spite of the lower viable count at the end of fermentation $\left(7.95 \times 10^{9} \mathrm{cfu} / \mathrm{mL}\right)$, the viable count of cells in the freeze-dried powder was $5.7 \times 10^{10}$ $\mathrm{cfu} / \mathrm{g}$, showing a higher survival of $55.3 \%$. Additionally, the average length of $L b$. bulgaricus ND02 cells was 2.04 $\mu \mathrm{m}$ (ranging from 1.26 to $2.94 \mu \mathrm{m}$ ) in yeast extract-free medium, whereas in medium containing yeast extract, cell length ranged from 3.5 to $6.22 \mu \mathrm{m}$, with an average of $4.54 \mu \mathrm{m}$.

Carvalho et al. (2004) noted that the nutrient composition of fermentation medium had a great effect on the survivability of lactic acid bacteria during freezedrying. Wright and Klaenhammer $(1981,1983)$ showed that availability of $\mathrm{Ca}^{2+}$ played a significant role in the survivability of $L b$. acidophilus and Lb. bulgaricus to freezing and freeze-drying. The authors also noted that lower $\mathrm{pH}$ facilitated the availability of $\mathrm{Ca}^{2+}$. Furthermore, the presence of $\mathrm{Mn}^{2+}$, sucrose, Tween-20, or Tween- 80 had a positive effect on the cryostability of lactobacilli and other bacteria (Smittle et al., 1972; Fonseca et al., 2001; Carvalho et al., 2003; Li et al., 2012). The effect of lactose starvation on cryotolerance of $L b$. acidophilus RD758 was investigated by Wang et al. (2011); they found greater cryotolerance in lactosestarved cells than cells grown with lactose.

\section{Effect of Fermentation $\mathrm{pH}$ on the Cryotolerance of Lb. bulgaricus NDO2}

The summary of results of growing Lactobacillus bulgaricus ND02 at pH 5.7 and 5.1 is shown in Table 2. When the strain was grown in MRS broth in a fermen- tor set at a $\mathrm{pH}$ of 5.7 , the viable count at the end of fermentation was $8.9 \times 10^{9} \mathrm{cfu} / \mathrm{mL}$, twice the count obtained at a $\mathrm{pH}$ of 5.1. However, the survival of cells grown at $\mathrm{pH} 5.7$ was lower than that of cells controlled at $\mathrm{pH}$ 5.1. Viable counts of the lyophilized powder of Lb. bulgaricus ND02 cultivated at $\mathrm{pH} 5.1$ reached 1.05 $\times 10^{11} \mathrm{cfu} / \mathrm{g}$, and the survival of the freeze-drying process was $68.3 \%$, whereas at $\mathrm{pH} 5.7$, survival was only $51.2 \%$. This is significant in industrial production of Lactobacillus bulgaricus ND02, because greater survival will result in higher functionality (acid production in milk). Further, the amount of neutralizer consumed during fermentation was greater at $\mathrm{pH}$ 5.7. Probably because of the more acid environment encountered at $\mathrm{pH}$ 5.1, the growth of bacteria was slower and required more time to finish the fermentation.

Figures 1 and 2 depict micrographic images of $L b$. bulgaricus ND02 cells grown at pH 5.1 and 5.7, respectively. Cells grown at the lower $\mathrm{pH}$ were shorter and more compact. Some cells displayed a curved and even semicircular and circular morphology. Occurrence of this phenomenon may be due to the over-acidic culture environment, which made the growth of bacteria react to the surrounding environmental conditions. Cells from the fermentation controlled at $\mathrm{pH} 5.7$ were relatively longer and straighter. As observed in this experiment and in the comparison of cells grown in the absence of yeast extract versus those grown in the presence of yeast extract, we found a correlation between the length of the cells and cryostability: the shorter the cells, the greater their cryostability. We previously studied the response of the yogurt starter strain Streptococcus thermophilus ND03 to high-cell-density cultivation and vacuum freeze-drying. We found that the vacuum freeze-drying survival of Streptococcus thermophilus ND03 (Sun et al., 2011b) could reach 90 or $100 \%$ (Zhang, 2011). Streptococcus thermophilus is small and globular, a different morphology from the baculiform lactobacilli. Consequently, morphology is an influential factor for the survival of the bacteria.

Earlier reports have suggested that injury and lethality of cells during freezing could be brought about by ice crystal formation within cells, and formation of larger ice crystals could puncture the cell membrane, resulting in loss of semi-permeability and collapse of some the 


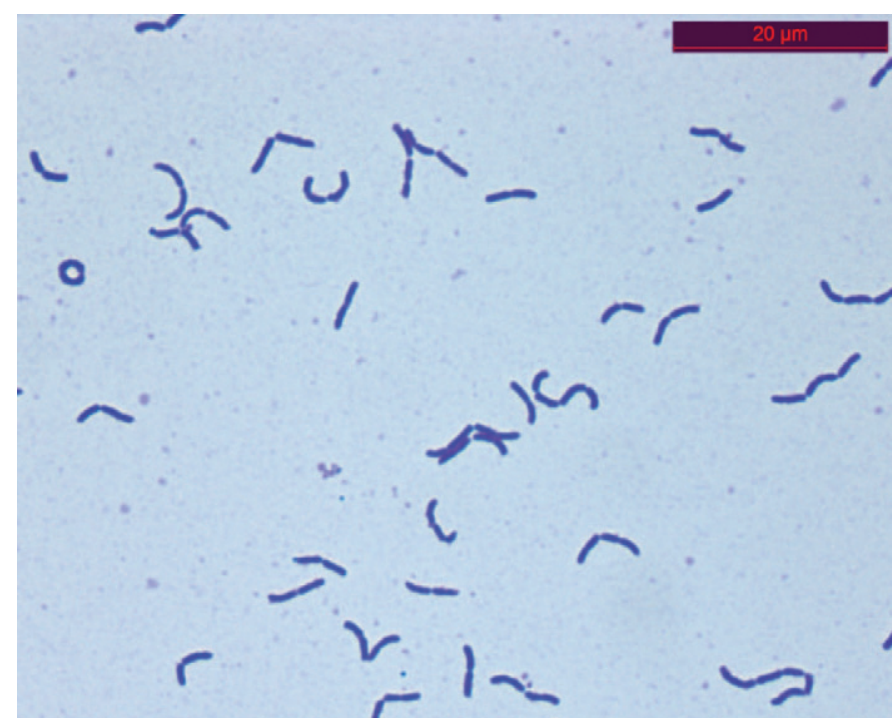

Figure 1. Morphology of Lactobacillus bulgaricus ND02 cultivated at a constant $\mathrm{pH}$ of 5.1. Color version available in the online PDF.

cell membrane-associated proton-motive force (PMF) systems. It appears that long filamentous cells are more liable to such injury, whereas shorter, more compact cells are relatively resistant to such events. Several reports in the literature show that shorter, compact cells are relatively more resistant to freezing than longer, filamentous cells. Koch et al. (2008), working with a strain of Lactobacillus delbrueckii ssp. lactis FAM10991, which was sensitive to freezing and lyophilization, found that the strain grown at $\mathrm{pH} 5.0$ exhibited 20- to 45 -fold higher survival after freeze-drying than cells grown at pH 6.0. Palmfeldt and Hahn-Hägerdal (2000)

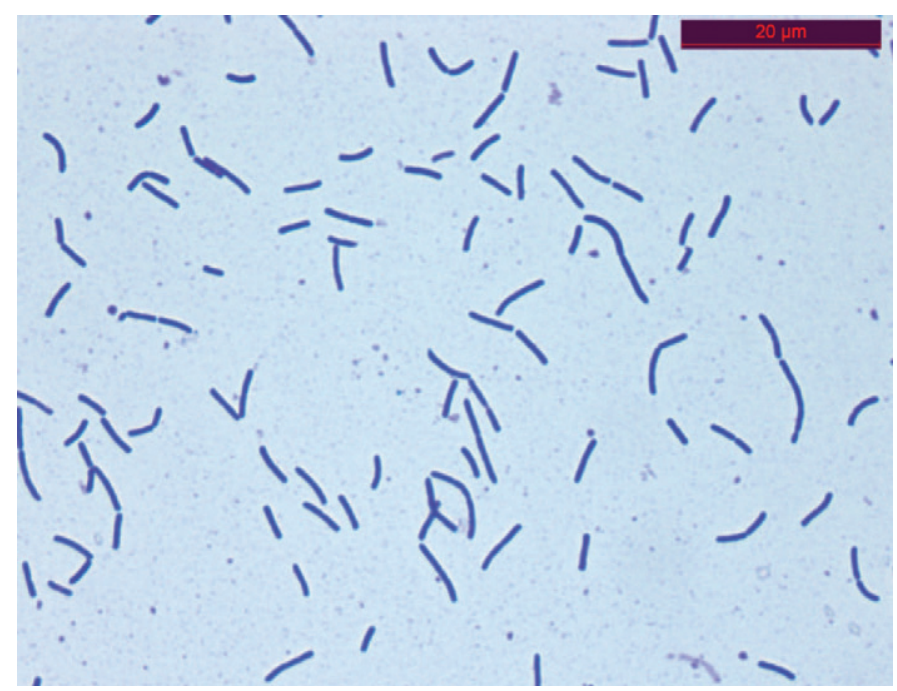

Figure 2. Morphology of Lactobacillus bulgaricus ND02 cultivated at a constant $\mathrm{pH}$ of 5.7. Color version available in the online PDF. showed that cells of Lactobacillus reuteri ATCC 55730 grown at $\mathrm{pH} 5.0$ had a cell dimension of 2 to $4 \mu \mathrm{m}$ and frequently occurred in pairs, whereas cells grown at $\mathrm{pH}$ 6.0 were longer (4 to $15 \mu \mathrm{m}$ long) and occurred as single cells. The same study reported that cells showing the shorter, more compact morphology (grown at $\mathrm{pH}$ 5.0), survived cryoprocessing much better than cells grown at $\mathrm{pH}$ 6.0, which were longer. Wang et al. (2005a) found that for good survival after freeze-drying, Lb. acidophilus $\mathrm{RD} 758$ had to be grown at $30^{\circ} \mathrm{C}$ and a $\mathrm{pH}$ of 5.0 .

Other aspects of $\mathrm{pH}$ control have been investigated. Fonseca et al. (2001) reported that the use of $\mathrm{NaOH}$ as the neutralizer for constant $\mathrm{pH}$ control was preferable for a greater cryotolerance of lactic acid bacteria. In our research, we used $\mathrm{NH}_{4} \mathrm{OH}$ as the neutralizer to validate its suitability.

\section{Profiles of Cold Shock-Induced Genes cspA and cspB}

Quantitative PCR was conducted to investigate the effect of the cold-shock pretreatment at different temperatures on the expression of csp genes of 4 different $L b$. bulgaricus strains. The $\mathrm{qPCR}$ amplification plots are shown in Figure 3. The relative expression levels of $\operatorname{csp} \mathrm{A}$ of $L b$. bulgaricus ND02 after cold pretreatment at $10^{\circ} \mathrm{C}$ showed a 1.7 -fold increment over that after $4^{\circ} \mathrm{C}$ treatment. The expression of $\operatorname{csp} \mathrm{A}$ after $10^{\circ} \mathrm{C}$ pretreatment exhibited the greatest increase. However, at higher cold-shock treatment temperatures of 15 and $18^{\circ} \mathrm{C}$, the relative quantity of gene expression (RQ values) decreased to 0.51221 and 0.46188 , respectively (not shown in figure). All the other strains used in this study showed similar trends for pretreatment temperatures examined. Of the 4 strains tested, strains ND02 and IMAU80423 recorded higher RQ values. These 2 strains also gave higher cryostability in an earlier study (Bao, 2012) and in the present study.

Similar variations in the trends of the expression of $c s p \mathrm{~B}$ with cold-shock pretreatment were found for all 4 strains (Figure 4). All strains responded favorably to pretreatment at $10^{\circ} \mathrm{C}$ for $2 \mathrm{~h}$. Observations made in these experiments revealed that for high expression of both $\operatorname{csp}$ genes, pretreatment at $10^{\circ} \mathrm{C}$ for $2 \mathrm{~h}$ is necessary.

\section{Profiles of Heat Shock-Induced Genes}

Expression of heat shock-induced genes for the 4 strains was examined using pretreatment at 30,37 , and $45^{\circ} \mathrm{C}$ for $30 \mathrm{~min}$. The trends of RQ values for 4 strains of the $6 h s p$ genes (groES, hsp, hsp20, hsp40, hsp60, and $h s p 70)$ are depicted in Figure 5. The expression of $h s p$ and hsp60 genes showed similar patterns for all 4 


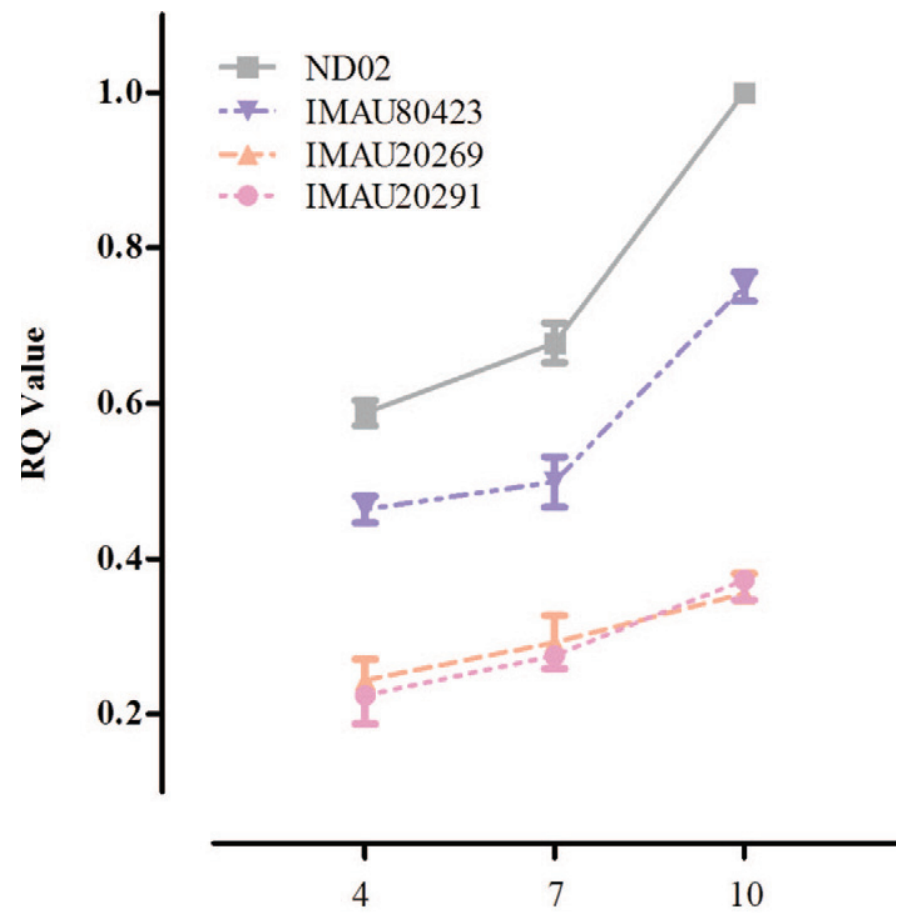

Pre-treatment temperature $\left({ }^{\circ} \mathrm{C}\right)$

Figure 3. Expression of cold-shock gene csp A in 4 Lactobacillus bulgaricus strains (ND02, IMAU80423, IMAU20269, IMAU20291) with different pretreatment temperatures. $\mathrm{RQ}$ value = relative quantity of expression of cold-shock gene csp $\mathrm{A}$ in 4 Lactobacillus bulgaricus strains (ND02, IMAU80423, IMAU20269, and IMAU20291) with different pretreatment temperatures. Color version available in the online PDF.

strains. No hsp40 and hsp70 genes were expressed by $L b$. bulgaricus IMAU20269, and we observed no expression of $h s p 70$ gene by strain IMAU80423. In general, $37^{\circ} \mathrm{C}$ pretreatment yielded higher responses for the following genes: $h s p, h s p 40, h s p 60$, and $h s p 70$. In strains ND02 and IMAU20291, the expression of groES was greater following $45^{\circ} \mathrm{C}$ pretreatment. The expression of hsp 20 by strain IMAU20269 was higher compared with other strains at $45^{\circ} \mathrm{C}$. Of the $4 \mathrm{Lb}$. bulgaricus strains tested, strain ND02 exhibited relatively higher heatshock gene expression with pretreatment at $37^{\circ} \mathrm{C}$ for 30 min. This was reflected in greater survivability of strain ND02 after freeze-drying (Tables 3 and 4). Broadbent and Lin (1999) reported that heat-shocking at $42^{\circ} \mathrm{C}$ for $25 \mathrm{~min}$ increased the resistance to freezing in Lactococcus lactis ssp. lactis and heat-shocking at $39^{\circ} \mathrm{C}$ for 25 min boosted the cryotolerance of Lactococcus lactis ssp. cremoris. An increase in the cryoresistance of the subspecies lactis and cremoris was achieved by cold-shock treatment at $10^{\circ} \mathrm{C}$ for $2 \mathrm{~h}$. Fiocco et al. (2007) found that overproduction of heat-shock protein improved the growth of Lactobacillus plantarum at $37^{\circ} \mathrm{C}$ and $40^{\circ} \mathrm{C}$.
Three species of Lactobacillus were investigated by characterizing their heat responses at $30^{\circ} \mathrm{C}$ and $37^{\circ} \mathrm{C}$ after an incubation of $20 \mathrm{~min}$, and thermo-tolerance experiments showed that pretreatment improved the ability of 3 Lactobacillus strains to withstand a 20-min higher temperature (Broadbent et al., 1997).

\section{Comparative Evaluation of Survival of Untreated and Pretreated Cells of 4 Lb. bulgaricus Strains to Freeze-Drying}

Using the data obtained in this study for optimal propagation of the $4 \mathrm{Lb}$. bulgaricus strains (without yeast extract in the propagation medium and controlling $\mathrm{pH}$ at 5.1 during fermentation), cells pretreated at $10^{\circ} \mathrm{C}$ for $2 \mathrm{~h}$ and $37^{\circ} \mathrm{C}$ for 30 min (optimum treatments for the expression of $c s p$ and $h s p$ genes) were subjected to freeze-drying. In parallel, cells similarly propagated but without any pretreatment were lyophilized. Using the formula for determining the percentage survival as described in the Methods section, we evaluated the survival of the 2 cell crops. The methodology is summa-

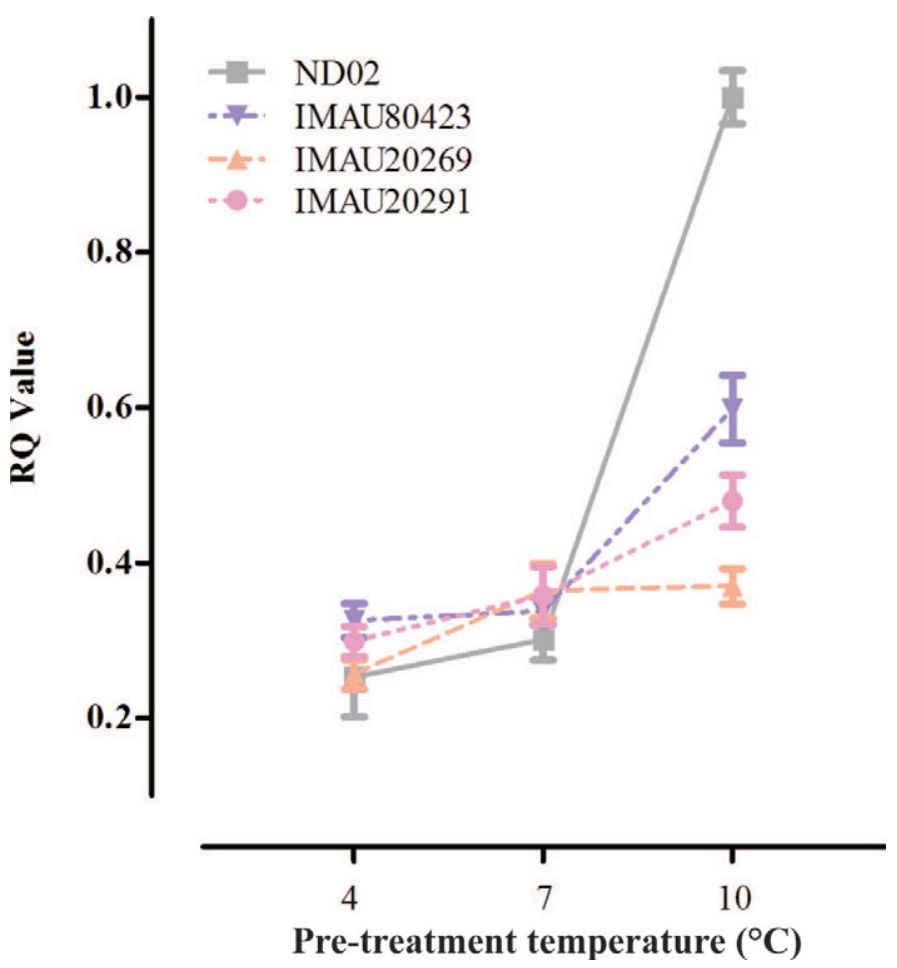

Figure 4. Expression of cold-shock gene cspB in 4 Lactobacillus bulgaricus strains (ND02, IMAU80423, IMAU20269, IMAU20291) with different pretreatment temperatures. $\mathrm{RQ}$ value = relative quantity of expression of cold-shock gene $c s p \mathrm{~B}$ in 4 Lactobacillus bulgaricus strains (ND02, IMAU80423, IMAU20269, and IMAU20291) with different pretreatment temperatures. Color version available in the online PDF. 
A)

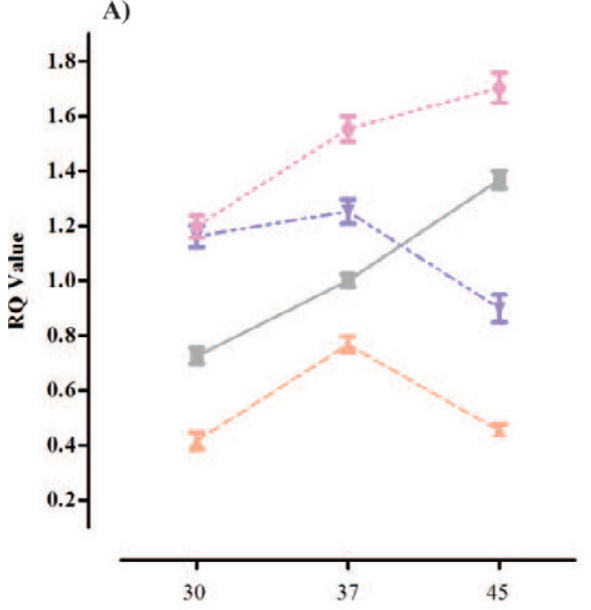

B)

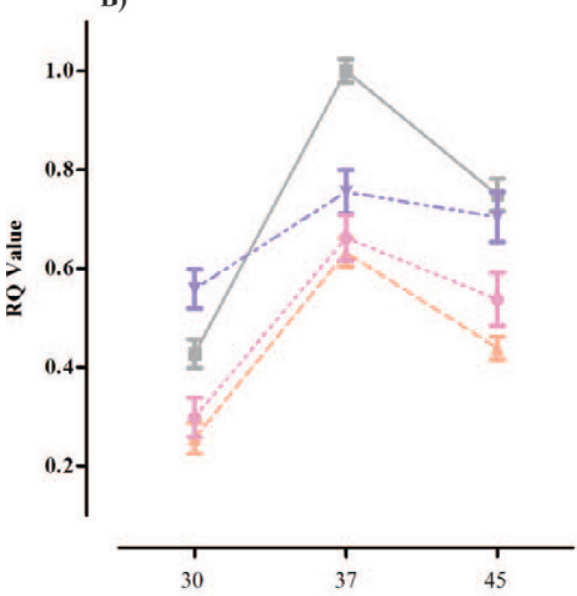

C)

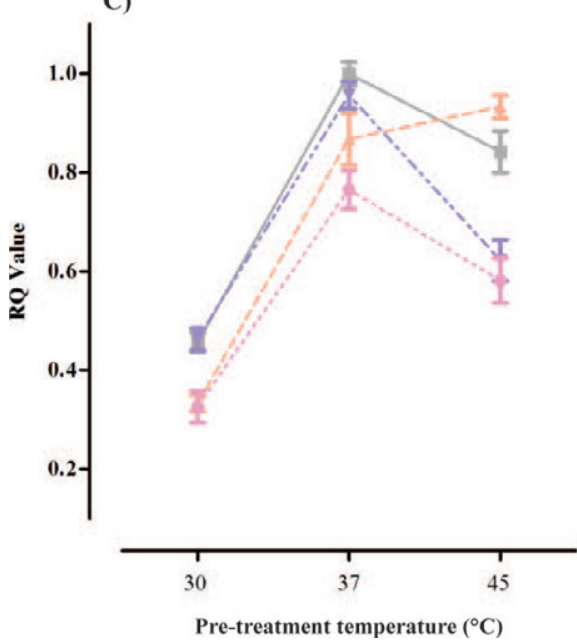

D)

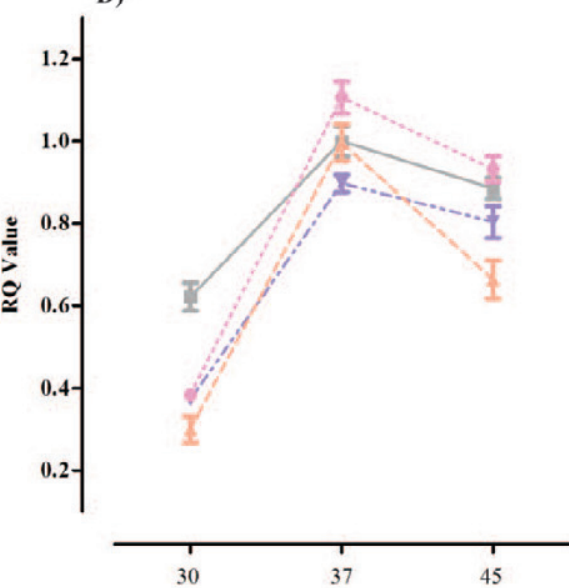

E)

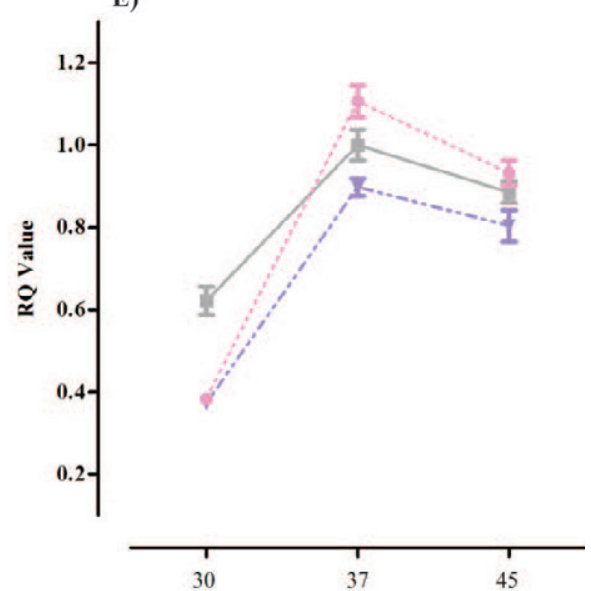

F)

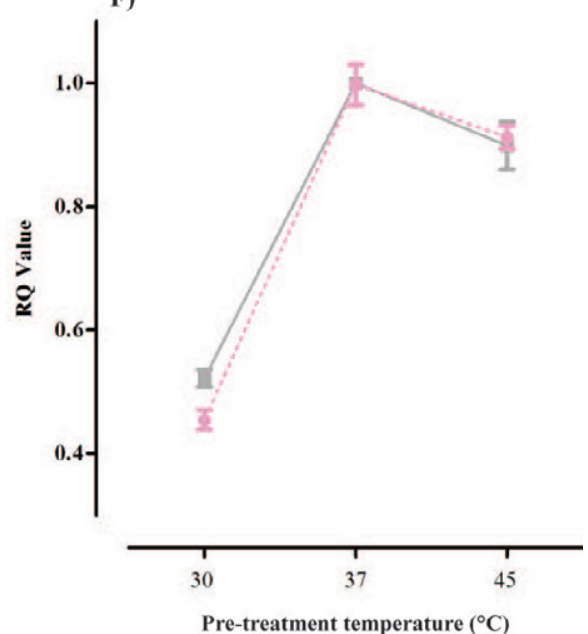

Figure 5. Expression of heat-shock genes groES, hsp, hsp20, hsp60, hsp40, and hsp70 (A to F, respectively) of 4 different Lactobacillus bulgaricus strains (ND02, IMAU80423, IMAU20269, IMAU20291). RQ value = relative quantity of expression of heat-shock genes groES, $h s p$, $h s p 20, h s p 60, h s p 40$, and $h s p 70$ (A to F, respectively) in 4 Lactobacillus bulgaricus strains (ND02, IMAU80423, IMAU20269, and IMAU20291) with different pretreatment temperatures. Color version available in the online PDF. 
Table 3. Experimental protocol used to compare untreated versus treated cells

\begin{tabular}{lccc}
\hline Technology & No pretreatment & $10^{\circ} \mathrm{C}$ pretreatment & $37^{\circ} \mathrm{C}$ pretreatment \\
\hline Culture medium & de Man, Rogosa, and Sharpe without yeast extract \\
Fermentation temperature & & $37^{\circ} \mathrm{C}$ & \\
Initial pH value & & 5.5 & \\
Constant pH value & None & $10^{\circ} \mathrm{C}$ for $2 \mathrm{~h}$ & $37^{\circ} \mathrm{C}$ for $30 \mathrm{~min}$ \\
Pretreatment & & $-40^{\circ} \mathrm{C}$ for $2.5 \mathrm{~h}$ & \\
Freezing before lyophilization & & & \\
\hline
\end{tabular}

rized in Table 3 and the results of the survivability after lyophilization are shown in Table 4 . From the results presented in Table 4, it can be seen that pretreatment of cells resulted in greater survival after freeze-drying across the board. However, the greatest increment in survival was noted with strains IMAU20269 and IMAU20291, with pretreatment at $10^{\circ} \mathrm{C}$ for $2 \mathrm{~h}$ and at $37^{\circ} \mathrm{C}$ for $30 \mathrm{~min}$. The overall results indicated that pretreatment of cells before freeze-drying protected them from stress generated during the drying process.

\section{Evaluating the Functionality of Pretreated Lb. bulgaricus Cells After Freeze-Drying}

Merely obtaining better survival after freeze-drying of pretreated cells was not the goal in this study. Loss or impairment of functionality in freeze-dried pretreated cells would not be of much of a gain in developing this technology. Therefore, cells of the $4 \mathrm{Lb}$. bulgaricus strains lyophilized without pretreatment were evaluated against pretreated cells for acid production in milk under standard incubation conditions. The results are presented in Table 5. The acid-producing activity in milk was not decreased or impaired by pretreatment. We observed no significant differences between the functionality of untreated and treated freeze-dried cells. Additionally, we found no differences between the treated and untreated cells with respect to body (viscosity), texture (smoothness), water-holding capacity, or flavor (mildness) of the fermented product. Several similar studies were previously reported. Lactobacillus plantarum strain WCFS1 was studied to detect the effect of heat shock on overproduction of the heat-shock proteins. After 2 heat treatments of $37^{\circ} \mathrm{C}$ and $40^{\circ} \mathrm{C}$ in a water bath, the functionality of the pretreated strains were almost unaffected and no significant differences were observed between the strains (Fiocco et al., 2007). Prasad et al. (2003) found that Lactobacillus rhamnosus HN001, when prestressed at $50^{\circ} \mathrm{C}$, showed significant improvement in viability.

\section{CONCLUSIONS}

This research was designed to improve the survival of Lactobacillus bulgaricus strains after freeze-drying. The techniques developed will benefit commercial production of starter strains for large-scale manufacture of yogurt and high-cook cheese such as Swiss cheese varieties and Italian cheeses. With the growing popularity of yogurt in China, the need for reliable $L b$. bulgaricus-containing starters will be important. The production of superior starter cultures consists of a series of complex steps, and it is necessary that every step in the production must be considered. The extension of these findings to other Lb. bulgaricus strains of differing phage susceptibilities and pairing with compatible Streptococcus thermophilus strains would provide a series of starters that could be used in rotation to manage phage-related problems in the yogurt and cheese industry. This paper has provided some guidelines in the production of highquality starters and should stimulate further research in this area.

Table 4. Survival (\% $\pm \mathrm{SD})$ of Lactobacillus bulgaricus after freeze-drying untreated and treated cells

\begin{tabular}{|c|c|c|c|c|c|}
\hline \multirow[b]{2}{*}{ Strain } & \multirow[b]{2}{*}{ No pretreatment } & \multicolumn{2}{|c|}{$10^{\circ} \mathrm{C}$ pretreatment } & \multicolumn{2}{|c|}{$37^{\circ} \mathrm{C}$ pretreatment } \\
\hline & & Survival & $\Delta \mathrm{R}^{1}$ & Survival & $\Delta \mathrm{R}$ \\
\hline ND02 & $71.70 \pm 1.00^{\mathrm{a}}$ & $79.81 \pm 0.81^{\mathrm{a}}$ & $8.11 \pm 0.31^{\mathrm{b}}$ & $77.32 \pm 0.44^{\mathrm{a}}$ & $5.62 \pm 0.70^{\mathrm{b}}$ \\
\hline IMAU 80423 & $60.50 \pm 2.61^{\mathrm{b}}$ & $70.02 \pm 1.64^{\mathrm{b}}$ & $9.52 \pm 1.02^{\mathrm{b}}$ & $65.32 \pm 2.18^{\mathrm{b}}$ & $4.82 \pm 0.44^{\mathrm{c}}$ \\
\hline IMAU20269 & $45.83 \pm 1.15^{\mathrm{c}}$ & $61.89 \pm 0.82^{\mathrm{c}}$ & $16.06 \pm 0.42^{\mathrm{a}}$ & $58.88 \pm 0.15^{\mathrm{c}}$ & $13.05 \pm 1.01^{\mathrm{a}}$ \\
\hline IMAU20291 & $46.72 \pm 0.39^{\mathrm{c}}$ & $63.54 \pm 1.32^{\mathrm{c}}$ & $16.82 \pm 0.93^{\mathrm{a}}$ & $60.06 \pm 0.24^{\mathrm{c}}$ & $13.48 \pm 0.38^{\mathrm{a}}$ \\
\hline
\end{tabular}

${ }^{\mathrm{a}-\mathrm{c}}$ Means within a row with different superscripts differ $(P<0.05)$.

${ }^{1} \Delta \mathrm{R}=$ difference of survival compared with no pretreatment. 
Table 5. Functionality $[\mathrm{pH}$ and titratable acidity $(\mathrm{TA} ; \pm \mathrm{SD})]$ of Lactobacillus bulgaricus cells with and without pretreatment

\begin{tabular}{|c|c|c|c|c|c|}
\hline \multirow[b]{2}{*}{ Freeze-drying method } & \multirow[b]{2}{*}{ Strain } & \multicolumn{2}{|r|}{$4 \mathrm{~h}$} & \multicolumn{2}{|r|}{$6 \mathrm{~h}$} \\
\hline & & $\mathrm{pH}$ & $\mathrm{TA}\left({ }^{\circ} \mathrm{T}\right)$ & $\mathrm{pH}$ & $\mathrm{TA}\left({ }^{\circ} \mathrm{T}\right)$ \\
\hline \multirow[t]{4}{*}{ No pretreatment } & ND02 & 5.16 & $46.89 \pm 2.72$ & 4.67 & $60.71 \pm 1.60$ \\
\hline & IMAU80423 & 5.22 & $44.10 \pm 3.11$ & 4.74 & $56.29 \pm 0.78$ \\
\hline & IMAU20269 & 5.32 & $41.76 \pm 4.89$ & 4.81 & $52.78 \pm 3.54$ \\
\hline & IMAU20291 & 5.38 & $40.23 \pm 1.22$ & 4.89 & $52.73 \pm 4.83$ \\
\hline \multirow[t]{4}{*}{$10^{\circ} \mathrm{C}$ pretreatment } & ND02 & 5.14 & $47.76 \pm 1.18$ & 4.62 & $61.27 \pm 3.01$ \\
\hline & IMAU80423 & 5.23 & $43.95 \pm 3.51$ & 4.69 & $58.73 \pm 2.16$ \\
\hline & IMAU20269 & 5.33 & $43.10 \pm 1.58$ & 4.77 & $55.28 \pm 1.00$ \\
\hline & IMAU20291 & 5.4 & $40.46 \pm 2.02$ & 4.85 & $52.62 \pm 3.39$ \\
\hline \multirow[t]{4}{*}{$37^{\circ} \mathrm{C}$ pretreatment } & ND02 & 5.1 & $48.01 \pm 3.79$ & 4.68 & $59.69 \pm 0.94$ \\
\hline & IMAU80423 & 5.15 & $46.51 \pm 1.34$ & 4.71 & $55.99 \pm 1.26$ \\
\hline & IMAU20269 & 5.21 & $44.55 \pm 2.06$ & 4.78 & $54.33 \pm 1.00$ \\
\hline & IMAU20291 & 5.34 & $42.32 \pm 0.88$ & 4.9 & $53.01 \pm 3.56$ \\
\hline
\end{tabular}

\section{ACKNOWLEDGMENTS}

This research was supported by the National Natural Science Foundation of China (no. 31025019), the National High Technology Research and Development Program of China (863 program no. 2011AA100901, 2011AA100902), and China Agriculture Research System (grant no. CARS-37).

\section{REFERENCES}

Bâati, L., C. Fabre-Gea, D. Auriol, and P. J. Blanc. 2000. Study of the cryotolerance of Lactobacillus acidophilus: Effect of culture and freezing conditions on the viability and cellular protein levels. Int. J. Food Microbiol. 59:241-247.

Bao, W. C. 2012. The study on high cell density cultivation and freezedrying protection of Lactobacillus delbrueckii ssp. bulgaricus ND02. MS Thesis. Inner Mongolia Agricultural Univ., Huhhot, Inner Mongolia, China.

Broadbent, J. R., and C. Lin. 1999. Effect of heat shock or cold shock treatment on the resistance of Lactococcus lactis to freezing and lyophilization. Cryobiology 39:88-102.

Broadbent, J. R., C. J. Oberg, H. Wang, and L. Wei. 1997. Attributes of the heat shock response in three species of dairy Lactobacillus. Syst. Appl. Microbiol. 20:12-19.

Bukau, B. 1993. Regulation of the Escherichia coli heat-shock response. Mol. Microbiol. 9:671-680.

Carvalho, A. S., J. Silva, P. Ho, P. Teixeira, F. X. Malcata, and P. Gibbs. 2004. Relevant factors for the preparation of freeze-dried lactic acid bacteria. Int. Dairy J. 14:835-847.

Carvalho, A. S., J. Silva, P. Teixeira, F. X. Malcata, and P. Gibbs. 2003. Effect of various growth media upon survival during storage of freeze-dried Enterococcus faecalis and Enterococcus durans. J. Appl. Microbiol. 94:947-952.

Fiocco, D., V. Capozzi, P. Goffin, P. Hols, and G. Spano. 2007. Improved adaptation to heat, cold, and solvent tolerance in Lactobacillus plantarum. Appl. Microbiol. Biotechnol. 77:909-915.

Fonseca, F., C. Béal, and G. Corrieu. 2001. Operating conditions that affect the resistance of lactic acid bacteria to freezing and frozen storage. Cryobiology 43:189-198.

Hecker, M., and U. Völker. 1990. General stress proteins in Bacillus subtilis. FEMS Microbiol. Lett. 74:197-213.

Jones, P. G., M. Cashel, G. Glaser, and F. C. Neidhardt. 1992. Function of a relaxed-like state following temperature downshifts in Escherichia coli. J. Bacteriol. 174:3903-3914.

Koch, S., E. Eugster-Meier, G. Oberson, L. Meile, and C. Lacroix. 2008. Effects of strains and growth conditions on autolytic activity and survival to freezing and lyophilization of Lactobacillus delbrueckii ssp. lactis isolated from cheese. Int. Dairy J. 18:187-196. Komatsu, Y., S. C. Kaul, H. Iwahashi, and K. Obuchi. 1990. Do heat shock proteins provide protection against freezing? FEMS Microbiol. Lett. 60:159-162.

Li, C., L. B. Liu, and N. Liu. 2012. Effects of carbon sources and lipids on freeze-drying survival of Lactobacillus bulgaricus in growth media. Ann. Microbiol. 62:949-956.

Palmfeldt, J., and B. Hahn-Hägerdal. 2000. Influence of culture pH on survival of Lactobacillus reuteri subjected to freeze-drying. Int. J. Food Microbiol. 55:235-238.

Prasad, J., P. McJarrow, and P. Gopal. 2003. Heat and osmotic stress responses of probiotic Lactobacillus rhamnosus HN001 (DR20) in relation to viability after drying. Appl. Environ. Microbiol. 69:917-925.

Saarela, M., I. Virkajärvi, H. L. Alakomi, T. Mattila-Sandholm, A. Vaari, T. Suomalainen, and J. Mättö. 2005. Influence of fermentation time, cryoprotectant and neutralization of cell concentrate on freeze-drying survival, storage stability, and acid and bile exposure of Bifidobacterium animalis ssp. lactis cells produced without milkbased ingredients. J. Appl. Microbiol. 99:1330-1339.

Smittle, R. B., S. E. Gilliland, and M. L. Speck. 1972. Death of Lactobacillus bulgaricus resulting from liquid nitrogen freezing. Appl Microbiol. 24:551-554.

Storz, G., and R. Hengge-Aronis. 2000. Bacterial Stress Responses. ASM Press, Washington, DC.

Streit, F., G. Corrieu, and C. Béal. 2007. Acidification improves cryotolerance of Lactobacillus delbrueckii ssp. bulgaricus CFL1. J. Biotechnol. 128:659-667.

Streit, F., G. Corrieu, and C. Béal. 2010. Effect of centrifugation condition on the cryotolerance of Lactobacillus bulgaricus CFL1. Food Bioproc. Technol. 3:36-42.

Sun, Z. H., X. Chen, J. C. Wang, W. J. Zhao, Y. Y. Shao, Z. Guo, X. C. Zhang, Z. M. Zhou, T. S. Sun, L. Wang, H. Meng, H. P. Zhang, and W. Chen. 2011a. Complete genome sequence of $L$. delbrueckii ssp. bulgaricus strain ND02. J. Bacteriol. 193:3426-3427.

Sun, Z. H., X. Chen, J. C. Wang, W. J. Zhao, Y. Y. Shao, L. Wu, Z. M. Zhou, T. S. Sun, L. Wang, H. Meng, H. P. Zhang, and W. Chen. 2011b. Complete genome sequence of Streptococcus thermophilus strain ND03. J. Bacteriol. 193:793-794.

Sun, Z. H., W. J. Liu, W. Gao, M. Yang, J. C. Zhang, L. Wu, J. G. Wang, B. L. G. Menghe, T. S. Sun, and H. P. Zhang. 2010. Identification and characterization of the dominant lactic acid bacteria from kurut: The naturally fermented yak milk in Qinghai, China. J. Gen. Appl. Microbiol. 56:1-10.

Wang, Y., G. Corrieu, and C. Béal. 2005a. Fermentation pH and temperature influence the cryotolerance of Lactobacillus acidophilus RD758. J. Dairy Sci. 88:21-29. 
Wang, Y., J. Delettre, G. Corrieu, and C. Béal. 2011. Starvation induces physiological changes that act on the cryotolerance of Lactobacillus acidophilus RD758. Biotechnol. Prog. 27:342-350.

Wang, Y., J. Delettre, A. Guillot, G. Corrieu, and C. Béal. 2005b. Influence of cooling temperature and duration on cold adaptation of Lactobacillus acidophilus RD758. Cryobiology 50:294-307.

Willimsky, G., H. Bang, G. Fischer, and M. A. Marahiel. 1992. Characterization of $\operatorname{csp} B$, a Bacillus subtilis inducible cold shock gene affecting cell viability at low temperature. J. Bacteriol. 174:63266335 .

Wouters, J. A., J. W. Sanders, J. Kok, W. M. de Vos, O. P. Kuipers, and T. Abee. 1998. Clustered organization and transcriptional analysis of a family of five csp genes of Lactococcus lactis MG1363. Microbiology 144:2885-2893.
Wright, C. T., and T. R. Klaenhammer. 1981. Calcium-induced alteration of cellular morphology affecting the resistance of Lactobacillus acidophilus to freezing. Appl. Environ. Microbiol. 41:807-815.

Wright, C. T., and T. R. Klaenhammer. 1983. Survival of Lactobacillus bulgaricus during freezing and freeze-drying after growth in the presence of calcium. J. Food Sci. 48:773-777.

Zhang, H. P., and J. C. Zhang. 2007. Dairy Technology. China Light Industry Press, Beijing, China).

Zhang, X. C. 2011. The study on high cell density cultivation and freeze-drying protection of Streptococcus thermophilus. MS Thesis. Inner Mongolia Agricultural Univ., Huhhot, Inner Mongolia, China. 